\title{
Basement configuration of KG offshore basin from magnetic anomalies
}

\author{
V Subrahmanyam ${ }^{1}, \mathrm{~K}$ V Swamy ${ }^{2, *}$ and Neetha Raj ${ }^{2}$ \\ ${ }^{1}$ CSIR-National Institute of Oceanography, Regional Centre, Lawson's Bay Colony, Visakhapatnam 530 017, India. \\ ${ }^{2}$ Department of Geology, Adikavi Nannaya University, GSL SO, Rajahmundry 533 296, India. \\ *Corresponding author.e-mail: baalukandadai@yahoo.co.in
}

Marine magnetic anomalies along three representative profiles falling between shelf break and continentocean boundary in the offshore Krishna-Godavari basin were quantitatively interpreted for understanding the nature and structure of the magnetic basement using inversion technique. The interpretation of the anomalies shows that the magnetic basement lies deeper than the base of the sediments, i.e., acoustic basement identified by the seismic studies. This interpretation also shows that the magnetic basement is faulted along the NW-SE direction with the upthrown side lying to the north of the anomaly trend of this region. The coincidence of magnetizations observed through the present interpretation with that of charnockites of neighbouring EGMB and onshore $\mathrm{K}-\mathrm{G}$ basin areas indicates that EGMB geology (charnockites, granitic gneiss, etc.) extends up to COB in the offshore $\mathrm{K}-\mathrm{G}$ basin.

\section{Introduction}

The Eastern Continental Margin of India (ECMI) has been a seat of vigorous geophysical exploration for the last four decades. Its three major river basins, viz., the Cauvery, the Krishna-Godavari and the Mahanadi, are believed to be the result of the break-up of peninsular India from the combined Antarctica and Australia, and subsequent downwarping of the eastern part of the Indian shield (Sahni 1982). Hence, studies on ECMI and its river basins in particular would help one to understand the sequence of events that occurred during the break-up.

Of the three basins, the Krishna-Godavari $(\mathrm{K}-\mathrm{G})$ is a prominent petroliferous basin extending over an area of $28,000 \mathrm{~km}^{2}$ on land, 24,000 $\mathrm{km}^{2}$ in 'shallow' (up to $400 \mathrm{~m}$ ) waters and $18,000 \mathrm{~km}^{2}$ in deep waters (up to $2000 \mathrm{~m}$ ) (Sastri et al. 1973, 1974; Shenai and Rao 1982; Kumar 1983; Venkateswarlu et al. 1992a, b; Murthy et al. 1995).

The present communication reports the basement configuration of $\mathrm{K}-\mathrm{G}$ offshore basin, based on the analysis of magnetic anomaly data (figure 1) collected onboard RV Gaveshani and ORV Sagar Kanya along twenty-nine coast perpendicular traverses between $17^{\circ}$ and $14^{\circ} \mathrm{N}$ latitudes by National Institute of Oceanography, Regional Centre, Visakhapatnam.

The shelf edge, foot of the continental slope (FOS) identified from the bathymetry map (Subrahmanyam et al. 2010) of KG offshore basin and the continent ocean boundary (COB) derived from the gravity (Subrahmanyam et al. 2001) and seismic results (Gopala Rao et al. 1997) are presented along with the magnetic anomaly map in figure 1 .

Keywords. Marine magnetic anomalies; offshore K-G basin; magnetic basement; extension of EGMB geology; continentoceanic boundary. 


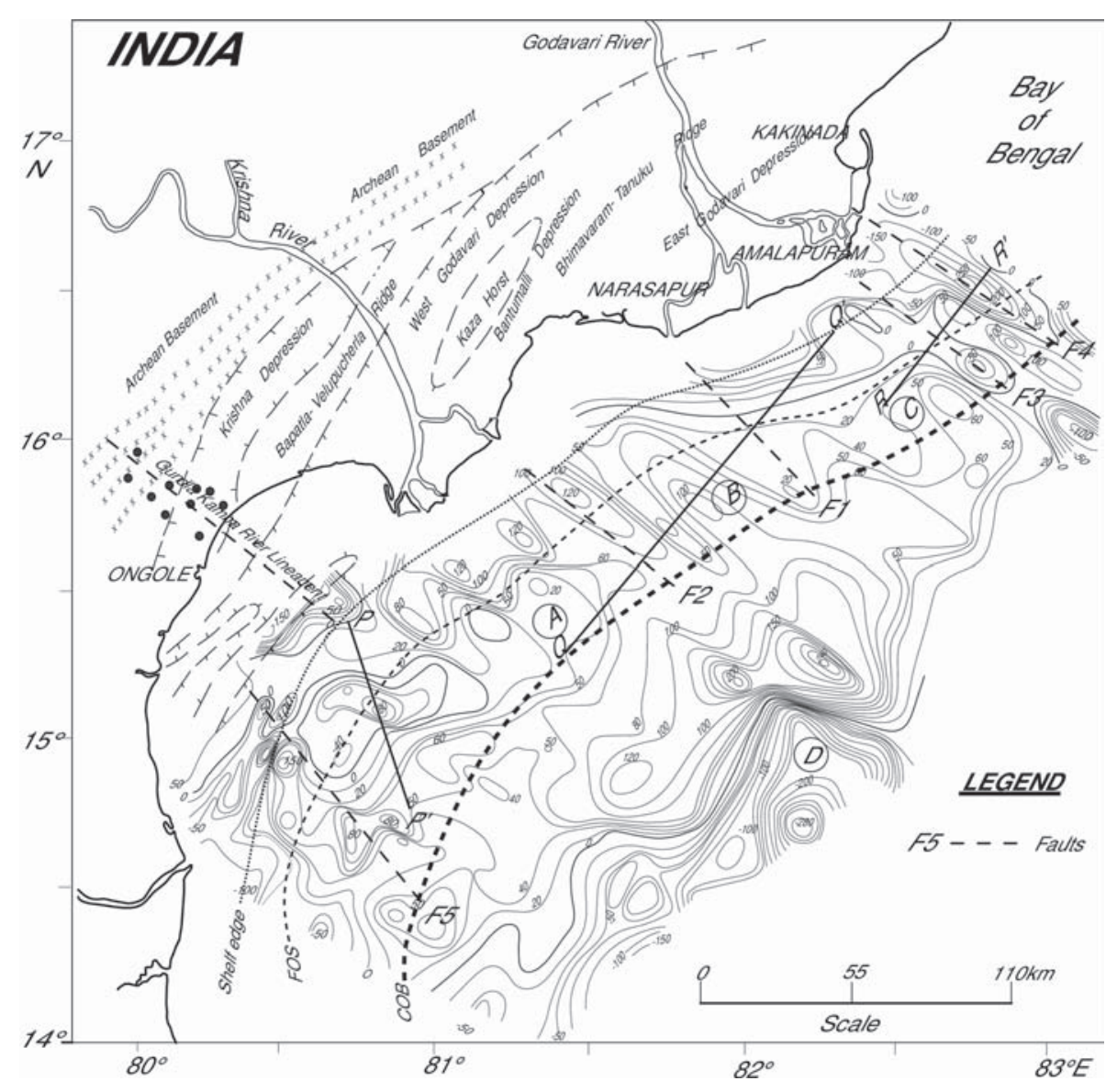

Figure 1. Total intensity magnetic anomaly contours over $\mathrm{K}-\mathrm{G}$ offshore basin. Zones $\mathrm{A}, \mathrm{B}, \mathrm{C}$ and the three representative profiles, $\mathrm{P}-\mathrm{P}^{\prime}, \mathrm{Q}-\mathrm{Q}^{\prime}$ and $\mathrm{R}-\mathrm{R}^{\prime}$ are shown. Land geology and tectonics are also shown.

\section{Magnetic anomalies of offshore $\mathrm{K}-\mathrm{G}$ basin and their character}

The magnetic anomaly contour map prepared at a variable contour interval brings out a conspicuous NE-SW trending anomaly pattern, over which several anomaly closures of varied amplitudes are superimposed. This anomaly map along with the single beam and multi-beam bathymetry data was earlier investigated qualitatively wherein the anomaly closures are attributed to the extension of the proved graben-horst type basement on land into the Bay of Bengal (Subrahmanyam et al. 2010). Several fault lineaments, e.g., F1, F2, F3, F4, and F5 were also identified based on the bathymetry signatures and magnetic anomaly trends. The fault lineaments F1 and F2 correlate well with land river lineaments of Godavari and Krishna rivers respectively indicating their probable offshore extension. The fault lineament F3 was shown as offshore extension of the major river Godavari, and F4, F5 indicating cluster of intrusions suggested by high frequency, short wavelength magnetic anomalies. The multi-beam bathymetry map off Narsapuram in the continental margin area (Pattan et al. 2008) brought out a NW-SE trending topographic rise extending towards the land and appearing to abut the trend of the Bhimavaram-Tanuku Ridge at the coast.

Based on the anomaly character, the study area can be divided into four zones, viz., A, B, C and D. While zones $\mathrm{A}, \mathrm{B}$, and $\mathrm{C}$ fall in the continental margin of $\mathrm{K}-\mathrm{G}$ basin area, zone $\mathrm{D}$ falls in the abyssal plains of Bay of Bengal. The anomaly zone $\mathrm{A}$ is sheared and shifted by an intervening NW-SE trending anomaly zone B bounded by the fault lineaments F1 and F2 (figure 1). In zone A, bounded by fault lineaments F5 and F2, the anomalies generally trend in SW-NE direction and have amplitudes between -80 and +120 nT. This zone is also associated with an isolated anomaly at $79^{\circ} 45^{\prime} \mathrm{E}$ longitude and $15^{\circ} \mathrm{N}$ latitude which is having a limited lateral extension, and of bi-polar nature. The zone B is associated with NW-SE trending anomaly closures with magnitudes varying between +40 and +120 nT lying between shelf edge and COB. These anomaly trends are earlier assumed to be due to the offshore extension of Bhimavaram-Tanuku Ridge (Subrahmanyam et al. 2010). Several smaller NW-SE anomaly closures of magnitudes varying between +50 and $+120 \mathrm{nT}$ can also be observed 
between coast and zone A which are interestingly terminating at shelf edge on the NW side and at FOS on the SE side. In contrast, zone $\mathrm{C}$ (lying in the northeastern end of the study area beyond the fault lineament F1) is associated with high frequency short wavelength NW-SE trending anomalies of amplitude varying between +20 and $-250 \mathrm{nT}$. This zone corresponds to the Godavari graben on the shore. Zone D, which falls in the abyssal plains of the Bay of Bengal is associated with a conspicuous NE-SW trending anomalous feature extending between $81^{\circ}-82.5^{\circ} \mathrm{E}$ longitudes and $14^{\circ}-16^{\circ} \mathrm{N}$ latitudes with amplitudes of anomalies varying between -280 and $+240 \mathrm{nT}$. This conspicuous feature was earlier attributed to a submerged volcano without giving any explanation to its origin (Venkateswarlu et al. 1992b). However, this anomalous feature when interpreted along with its associated gravity low could be attributed to a buried structural high formed by volcanic activity in a normal geomagnetic period after Cretaceous magnetic quiet period (Swamy et al. 2009).

\section{Inversion of magnetic anomalies}

In the present study, an attempt is made to interpret quantitatively the magnetic anomaly data falling under zones $\mathrm{A}, \mathrm{B}$ and $\mathrm{C}$ to understand the nature of magnetic basement in the area of continental margin of the offshore $\mathrm{K}-\mathrm{G}$ basin. For this purpose, several magnetic profiles lying between shelf edge and COB were constructed from the magnetic anomaly and inverted for the structure on magnetic interface using the FORTRAN programs, TMAG2DIN, TSHEETIN and others (Radhakrishna Murthy 1998). Three representative profiles, $\mathrm{P}-\mathrm{P}^{\prime}, \mathrm{Q}-\mathrm{Q}^{\prime}$ and $\mathrm{R}-\mathrm{R}^{\prime}$ falling one each in zones $\mathrm{A}, \mathrm{B}$ and $\mathrm{C}$ are presented in figure 2 along with the inferred structures. This inversion scheme TMAG2DIN assumes that the basement is magnetized in an unknown direction and the direction of magnetization is also estimated by trial and error. The program determines the initial values of depths to the magnetic interface below the anomaly points for the chosen magnetization and improves them iteratively, employing Marquardt's optimization algorithm. Similarly, the inversion scheme TSHEETIN attributes the anomalies to a thin horizontal sheet of matter and estimates its location and depth.

\subsection{Inversion of anomalies in zone $A$}

The interpreted magnetic basement under the profile $\mathrm{P}-\mathrm{P}^{\prime}$ in zone $\mathrm{A}$ along with the probable geological section below is shown in figure 2(a). This



Figure 2. Interpretation of magnetic anomalies along profiles $\mathrm{P}-\mathrm{P}^{\prime}, \mathrm{Q}-\mathrm{Q}^{\prime}$ and $\mathrm{R}-\mathrm{R}^{\prime}$ with probable geological crosssection above charnockite basement.

profile runs $70 \mathrm{~km}$ along the continental slope in NNW-SSE direction and falls between shelf break and COB. The interpreted magnetic basement below this profile lies deeper than the base of the sediments, i.e., acoustic/granitic basement marked as granite gneiss in figure 2(a), as adopted from the sediment thickness map (Curray 1991). The inferred magnetic basement typically shows an upwarp (or horst-like structure) in the middle 
of the profile $\mathrm{P}-\mathrm{P}^{\prime}$. It is at a mean depth of 4.0 $\mathrm{km}$ and is magnetized with an effective magnetization of $600 \mathrm{nT}$, dipping up at $40^{\circ}$. These values are in good agreement with those of inferred magnetizations of charnockites in the neighbouring areas of Eastern Ghat Mobile Belt (EGMB) and onshore $\mathrm{K}-\mathrm{G}$ basin (Radhakrishna Murthy and Bangaru Babu 2006; Swamy et al. 2008). It is therefore inferred that a magnetic basement is different from the acoustic basement and by analogy, it can be assumed to be constituted by charnockites. Thus a magnetic charnockite basement lies below the granitic basement in this offshore region also, as in the case of EGMB onshore. At the end of the profile, the magnetic basement appears to be touching the granitic basement beyond which the granitic/charnockitic basement may totally disappear. This situation is similar to the exposed charnockites in the onshore EGMB.

\subsection{Interpretation of anomalies in zone $B$}

The profile $\mathrm{Q}-\mathrm{Q}^{\prime}$ runs for $150 \mathrm{~km}$ in the NE-SW direction in the centre of the anomaly map across the NW-SE trending anomaly of zone B. This profile also lies between the shelf break and COB. The interpreted magnetic basement under this profile with the probable geological section is shown in figure 2(b). Inversion of the anomalies along this profile puts the magnetic basement at a mean depth of $5.0 \mathrm{~km}$ with an effective intensity of magnetization of $700 \mathrm{nT}$ again dipping up at $70^{\circ}$ which are again in agreement with that of charnockites onshore. Interestingly, the magnetic basement in this case also lies below the granitic basement. However, it shows a downwarp from its mean depth showing no sign of a rise as observed in the multibeam bathymetric map off Narsapur to justify the seaward extension of Bhimavaram-Tanuku Ridge at the coast. As the magnetization of the basement rocks thus obtained in this case also agrees with those of the charnockites, it can be concluded that the magnetic basement in this zone B is also composed of charnockites.

\subsection{Interpretation of anomalies in zone $C$}

The profile $\mathrm{R}-\mathrm{R}^{\prime}$, which was constructed across the high frequency short wavelength anomaly features (NW-SE trending) falling in this zone C was unsuccessfully tried for a possible basement structure using the same TMAG2DIN program. This attempt brought out the magnetic basement lying at depths of $3-3.5 \mathrm{~km}$, which cannot be justified as the minimum sediment thickness observed from the sediment thickness map (Curray 1991) or the depth to the granitic/acoustic basement is around $4.6 \mathrm{~km}$.
However, the profile was successfully inverted for faulting in the magnetic basement, using the model of semi-infinite horizontal sheet (figure 2c) using the FORTRAN program TSHEETIN (Radhakrishna Murthy 1998) developed based on the Werner deconvolution technique. This inversion scheme not only estimates the model parameters, but also the linear regional anomaly trend. The calculated depth $(5.1 \mathrm{~km})$ in this method corresponds to the depth to the center of the sheet. Thus for a throw of $1 \mathrm{~km}$ the depths to the top and bottom of the magnetic basement will be 4.6 and $5.6 \mathrm{~km}$ respectively with an intensity of magnetization of $1030 \mathrm{nT}$ dipping at $53^{\circ}$.

This interpretation shows that the magnetic basement is faulted along the NW-SE direction with the upthrown side lying to the north of the anomaly trend of this region. This is consistent with the known data for the depth to the acoustic basement, which is shallow in the northern side compared to the southern side of the anomaly C. Further, this anomaly trend corresponds to the onshore Godavari graben, whose magnetic anomalies required the assumption of a faulted magnetic basement to explain its anomalies. The offshore situation is thus no different to the onshore situation.

\section{Discussion}

The present interpretation of magnetic anomalies along the three profiles in the offshore $\mathrm{K}-\mathrm{G}$ basin indicates that the magnetic basement lies deeper than the base of the sediments, i.e., the acoustic basement observed in the seismic sections. Thus it can be inferred that the magnetic basement is different from the acoustic basement. The magnetization of the basement rocks thus obtained in this present interpretation agrees well with those of the charnockites in the neighbouring onshore areas and, therefore, it can be concluded that the magnetic basement in this part of offshore $\mathrm{K}-\mathrm{G}$ basin is also composed of charnockites, which lies below the acoustic/granitic basement.

Australia, Antarctica and India have been a part of single landmass (eastern landmass of the Gondwanaland) during Precambrian times with EGMB and Enderby Land of eastern Antarctica forming a part of the Precambrian Gondwanaland Mobile Belt (Crawford 1974; Katz 1989; Fedarov et al. 1982). It is also evidenced through the geological and geochronological correlations that the combined India and East Antarctica landmass experienced a widespread granulite facies metamorphic event at about 1000-1100 m.a. (Kroner 1980; Grew and Manton 1986; Aftalion et al. 1988; Yoshida 1988), because of which charnockites have been 
evolved and formed a part of EGMB and Enderby Land of eastern Antarctica. In the later stages, the breakup of the peninsular India from the combined Antarctica and Australia and subsequent downwarping of the eastern part of Indian shield formed three major river basins Cauvery, KrishnaGodavari and Mahanadi, along the east coast of India (Sastri et al. 1981; Sahni 1982) with COB along the ECMI forming the breakup line. Thus the coincidence of magnetizations observed through the present interpretation with that of charnockites of neighbouring EGMB and onshore $\mathrm{K}-\mathrm{G}$ basin areas indicate that EGMB geology (charnockites, granitic gneiss, etc.) extend up to COB in the offshore $\mathrm{K}-\mathrm{G}$ basin, with the COB being the seaward limit of the granulitic belt and for several coastal trends (Murthy et al. 1995; Subrahmanyam et al. 1995).

\section{Acknowledgements}

Authors are grateful to Dr S W A Naqvi, Director, NIO (CSIR), Goa and to Dr V S N Murty, Scientistin-Charge, Regional Centre, NIO, Visakhapatnam, India, for their encouragement. The authors are also thankful to Prof. I V Radhakrishna Murthy for his valuable suggestions to improve the manuscript. The first author Dr. V Subrahmanyam is grateful to CSIR, New Delhi for grant of Emeritus Fellowship under which this work was carried out. Neetha Raj is thankful to Dept. of Science \& Technology, New Delhi for granting the Junior Research Fellowship through Inspire Programme. This is NIO (CSIR) contribution no. 7132.

\section{References}

Aftalion M, Bowes D R, Dash B and Dempster T J 1988 Late proterozoic charnockites in Orissa, India: A U-Pb and Rb-Sr isotopic study; J. Geol. 96 663-676.

Crawford C 1974 Geological map of Antarctica; 1:5, M. Am. Geophy. Soc., New York.

Curray J R 1991 Possible green schist metamorphism at the base of a $22 \mathrm{~km}$ sedimentary section, Bay of Bengal; Geology 19 1097-1100.

Fedarov I V, Ravich M G and Hofmann J 1982 Geological comparison of the southeastern peninsular India and Sri Lanka with a part of East Antarctica (Enderby Land, MacRobertson Land, and Princess Elizabeth Land); In: Antarctic Geoscience (ed.) Craddock C, University of Wisconsin Press, Madison, pp. 73-78.

Gopala Rao D, Krishna K S and Sar D 1997 Crustal evolution and sedimentation history of the Bay of Bengal since the Cretaceous; J. Geophys. Res. 102(B8) 17,74717,768 .

Grew E S and Manton W I 1986 A new correlation of saphirine granulites in the Indo-Antarctic metamorphism terrane: Late Proterozoic dates from the Eastern Ghats Province of India; Precamb. Res. 33 123-137.
Katz M B 1989 Sri Lanka-Indian Eastern Ghats-East Antactica and the Australian Albany fraser mobile belt: Gross geochemistry, age relationships, and tectonics in Precambrian Gondwanaland; J. Geol. 97 646-648.

Kumar S P 1983 Geology and hydrocarbon prospects of Krishna-Godavari and Cauvery basins; Petrol. Asia J. 6 57-65.

Kroner A 1980 Pan African crustal evolution; Episodes $23-8$.

Murthy K S R, Subrahmanyam A S, Lakshminarayana S, Chandrasekhar D V and Rao T C S 1995 Some geodynamic aspects of Krishna-Godavari Basin, east coast of India; Cont. Shelf Res. 15 779-788.

Pattan J N, Parthiban G, Prakash Babu C, Khadge N H, Paropkari A L and Kodagali V N 2008 A note on geochemistry of surface sediments from Krishna-Godavari Basin, east coast of India; J. Geol. Soc. India 71 107-114.

Radhakrishna Murthy I V 1998 Gravity and magnetic interpretation in exploration geophysics; Geol. Soc. India Memoir 45363.

Radhakrishna Murthy I V and Bangaru Babu S 2006 Structure of charnockitic basement in a part of the KrishnaGodavari basin, Andhra Pradesh; J. Earth Syst. Sci. 115 387-393.

Sahni A 1982 The structure, sedimentation and evolution of India continental margins, In: The ocean basins and margins, Indian Ocean (eds) Nairn A E M and Stehli F G (New York: Plenum Press), pp. 353-398.

Shenai K R and Rao M S 1982 Exploration in the off-shore Godavari-Krishna basins; Bull. ONGC 19(2) 293-300.

Sastri V V, Sinha R N, Singh G and Murti K V S 1973 Stratigraphy and tectonics of sedimentary basins on the east coast of India; Am. Assoc. Petrol. Geol. Bull. 57 $655-678$.

Sastri V V, Venkatachala B S and Narayanan V 1974 Evolution of Mesozoic sedimentary basins on the east coast of India; J. Australian Petroleum Exploration Association $1429-41$.

Sastri V V, Venkatachala B S and Narayanan V 1981 The evolution of east coast of India; Palaeogeogr. Palaeoclimatol. Palaeoecol. 36 23-54.

Subrahmanyam A S, Lakshminarayana S, Chandrasekhar D V, Murthy K S R and Rao T C S 1995 Offshore structural trends from magnetic data over Cauvery Basin, east coast of India; J. Geol. Soc. India 46 269-273.

Subrahmanyam A S, Subrahmanyam V, Sarma K V L N S, Murty G P S and Murthy K S R 2010 Land-ocean tectonic signatures of the Krishna-Godavari Basin: a qualitative evaluation; Curr. Sci. 98 485-486.

Subrahmanyam V, Krishna K S, Radhakrishna Murthy I V, Sarma K V L N S, Maria Desa Ramana M V and Kamesh Raju K A 2001 Gravity anomalies and crustal structure of the Bay of Bengal; Earth Planet. Sci. Lett. 192 $447-456$.

Swamy K V, Radhakrishna Murthy I V, Krishna K S, Murthy K S R, Subrahmanyam A S and Malleswara Rao M M 2009 Magnetic anomalies of offshore KrishnaGodavari basin, Eastern Continental Margin of India; J. Earth Syst. Sci. 118 405-412.

Swamy K V, Rama Rao P and Radhakrishna Murthy I V 2008 Magnetic anomalies and basement structure of the Eastern Ghats Mobile Belt and southwest Krishna basin in parts of Prakasam district, Andhra Pradesh; Curr. Sci. $94262-268$.

Venkateswarlu P D, Raghava Rao A M V and Bose P K 1992a Marine magnetic anomalies and associated tectonics along the east coast of India; In: Rencent geoscientific studies in the Bay of Bengal and the Andaman Sea; Geol. Surv. India Spec. Publ. 29 61-70. 
Venkateswarlu P D, Sengupta B J, Raghava Rao A M V and Bose P K 1992b Marine magnetic indication of a possible submerged volcano off Machilipatnam in Bay of Bengal; J. Geol. Soc. India 39 197-203.
Yoshida M 1988 A reconnaissance geological survey of Sri Lanka and India 1985-1986 for comparing geology in Sri Lanka, India and Antarctica; Osaka City University; J. Geosci. 31 1-17.

MS received 11 May 2015; revised 30 November 2015; accepted 6 December 2015 